Waste and Resource Management Volume 167 Issue WR4

Zero-waste networks in construction and demolition in Portugal

Durão, Caixinhas, Osório-Peters et al.
Proceedings of the Institution of Civil Engineers

Waste and Resource Management 167 November 2014 Issue WR4

Pages 153-168 http://dx.doi.org/10.1680/warm.13.00032

Paper 1300032

Received 04/10/2013_Accepted 13/05/2014

Keywords: buildings, structures \& design/demolition/recycling \&

reuse of materials

\title{
Zero-waste networks in construction and demolition in Portugal
}

\section{Vera Durão}

Researcher, consultant, CEIFA ambiente, Lisbon, Portugal

João Caixinhas

Manager, Senior Researcher, CEIFA ambiente, Lisbon, Portugal

Suhita Osório-Peters

Manager, Senior researcher, CEIFA ambiente, Lisbon, Portugal

Emilia den Boer

Assistant Professor, Institute of Environment Protection Engineering,

Wroclaw University of Technology, Wroclaw, Poland, Wroclaw, Poland
Ian D. Williams

Professor of Applied Environmental Science, Centre for Environmental Sciences, Faculty of Engineering and the Environment, University of Southampton, Southampton, UK

Tony Curran

Research Fellow, Centre for Environmental Sciences, Faculty of Engineering and the Environment, University of Southampton, Southampton, UK

Andreas Pertl

Researcher, Institute of Waste Management, BOKU-University of Natural Resources and Life Sciences, Vienna, Austria

This paper presents the results of Portuguese case studies on developing an industrial network around a construction site and three zero-waste demolition projects. The case studies analysed to what extent it is possible to achieve a significant reduction of the solid waste produced and an overall decrease in energy and water consumption. The results show that the reduction targets could be achieved by implementation of good practices in waste management and the development of networks to allow an increase in the reuse and recycling rates of wasted materials and residual water. At the construction site, overall achievement of reduction rates was additionally enforced by the substitution of inputs with strong potential impacts on the decrease of fresh water consumption and greenhouse gas emissions along the supply chain.

\section{Introduction}

As a consequence of the economic recession at the beginning of the twenty-first century, the construction sector has experienced a severe crisis all over Europe, particularly in countries such as Portugal and Ireland. This is significant because the construction and demolition $(\mathrm{C} \& \mathrm{D})$ industry is a major contributor to individual nations' economies - it contributes $10 \%$ to the Portuguese economy and, in the UK, the construction industry employs 3 million people, generates $£ 100$ billion each year (Vadera et al., 2008) and contributes 10\% towards gross domestic product (GDP) (Smith et al., 2002). However, this sector has relatively high environmental impacts. In Europe, the C\&D sector contributes $10-33 \%$ of total waste arisings, comprising demolition waste $(40-50 \%)$, renovation waste $(30$ $50 \%$ ) and construction waste (10-20\%) (Balaras et al., 2007). A significant amount of energy is used in the C\&D industry; for example, about $10 \%$ of UK national energy consumption is used in the production and transport of construction products and materials (Environment Agency, 2011). Although most energy usage occurs during the operation of the building (Environment Agency, 2011), high energy consumption occurs during the construction phase and also during the manufacturing and processing of the materials that are to be used (Spence and Mulligen, 1995). The embodied energy of each of the materials used in construction is completely controlled by the designer and manufacturer and therefore these stages are vital when considering how to cut energy usage (Spence and Mulligen, 1995). Significant quantities of greenhouse gases (GHGs) are emitted during C\&D activities such as transporting workers, crushing and transporting aggregates, and materials extraction and manufacturing. The construction of buildings consumes $16 \%$ of total water used globally (Yan et al., 2009).

The economic crisis has pushed the sector to move its main focus from the construction of new buildings towards the rehabilitation of old buildings. Moreover, increases in energy and materials costs have also encouraged eco-innovation in materials, techniques and logistics, but the construction industry is a conservative sector in which changes are not readily accepted. However, due to political pressure, concerns about waste management and recycling are growing. In 2005, the Portuguese Environmental Agency estimated that $69 \%$ of C\&D waste produced was illegally disposed of, $26 \%$ was landfilled and only 5\% was sent for recycling (Miranda, 2009). In 2012, Pacheco Torgal (2012) reported that recycling rates in the Portuguese C\&D sector were lower than $40 \%$. However, the implementation of good practice schemes in the sector has recently been required by legislation (e.g. Decree-law no. 73/ 2011 demands the integration of at least 5\% of recycled materials in public works where technically feasible). 
Waste and Resource Management

Volume 167 Issue WR4
Zero-waste networks in

construction and demolition in

Portugal

Durão, Caixinhas, Osório-Peters

et al.
In traditional demolition methods and techniques, buildings are simply pulled down, generating huge quantities of mixed wastes. This makes segregation and reuse/recycling difficult or very expensive, so most of this waste is disposed of by way of landfill. Increasing prices for landfill disposal are likely to invert this trend, making reuse and recycling more attractive and providing materials for emerging markets. However, this will also require the development of deconstruction (or selective demolition) techniques. Under existing conditions, this option is not attractive for economic reasons (Coelho and Brito, 2010).

Although, not yet common, some key actors are evolving to a different paradigm, beyond legislation. Voluntary schemes for building certification are being applied in some high-profile projects, in particular by public promoters (like the case study in Torres Vedras described later in the paper). Some producers of construction materials (e.g. cork products) are also engaged in obtaining Environment Product Declarations (EPDs) for their products, which are International Organization for Standardization (ISO) normalised declarations by the manufacturer about the environmental impacts of a product over its lifecycle.

Demolition activities, as opposed to construction works, do not use raw materials. They have significantly less negative impact on resource depletion than construction activities. However, they have a higher impact on waste generation; in fact, most $C \& D$ waste arises at demolition sites. These negative impacts may be partially counterbalanced if the high reuse and recycling potential of C\&D waste is fully exploited; demolition activities may induce a positive indirect effect on resource depletion if the secondary materials resulting from $\mathrm{C} \& \mathrm{D}$ waste are used to substitute primary resources. In Portugal, only a small share of the total reuse and recycling potentials of C\&D waste is currently used.

The project ZeroWIN (Towards zero waste in industrial networks; www.zerowin.eu), scheduled to run from 2009 to 2014, is creating innovative technologies, waste-prevention methodologies, strategies and system tools based on the vision reported by Curran and Williams (2012) and specific approaches developed during the project (den Boer and Wolf 2011; den Boer et al., 2012). In this paper, the results of two case studies - the construction of a new building and three demolition projects - are presented and analysed. The first case study relates to the construction of an environmental education centre in Torres Vedras, west Portugal. The building awaits certification by the Portuguese sustainable construction scheme Lidera (an acronym for leading by environment for sustainable construction).

The overarching aim of the case studies was to build industrial networks around C\&D works (including producers of materials and components, owners or promoters, architects, waste managers and other players) to demonstrate that it is possible due to sustainable construction measures - to achieve 30\% reduction of GHG emissions, $75 \%$ reduction of fresh water consumption and 70\% reuse and recycling of materials.

A preliminary environmental impact assessment (EIA) revealed that, during demolition activities, GHG emissions are mainly produced by the demolition process itself (54\%), the sorting of waste $(29 \%)$ and the landfilling of inert material $(10 \%)$ (Obersteiner et al., 2012a). Direct energy needs on construction/ demolition sites mainly refer to fuel use in machines and transportation, and special attention was therefore given to all activities requiring the use of machinery with the specific goal of achieving maximum reduction of fuel use on site. Further emphasis was set on logistical aspects concerning both material inputs (supply chain) and outputs (waste) in order to reduce the overall GHG emissions to a minimum. The preliminary EIA also showed that the main consumption of fresh water on demolition sites comes from the same three activities as for GHG emissions (Obersteiner et al., 2012a). Consequently, on-site sorting of waste and avoiding landfill were deemed as priority goals.

Taking account of the economic and other interests of the stakeholders involved is crucial to the success of this type of project. The promoters of the construction projects specified their own interests as follows.

To reduce the costs of resource consumption and waste management during construction.

To reduce the costs of energy and water consumption by reusing water flows from other companies or activities.

- To integrate reused and recycled materials in the constructed building or using them in supporting infrastructures (e.g. in the yard and for supporting activities).

To improve their image (municipality, construction companies, waste managers, other companies involved in the network) by reference in newspapers and other communication means to environmentally sound practices, as this was viewed as an easy and immediate way to approach future clients and other interested parties (e.g. householders).

- To increase awareness about sustainable construction and develop the experience of the staff involved.

- To disseminate good practices and show that such practices are possible to implement through targeted dissemination activities.

To support the development of industrial networks and increase reuse and recycling activities that bring both economic and social benefits to the regions where these industries are located.

To reduce the costs of resource consumption and waste management during demolition to promote efficiency in demolition processes. 
- To increase awareness about selective demolition and materials management and to develop the experience of the staff involved.

The scope of the C\&D case studies covered construction works occurring on site as well as some external activities such as the selection of input materials and the destination of output materials. In this sense, the selection of suppliers, construction techniques, support activities where applicable (e.g. site cleaning, tools maintenance, dust control, etc.) and waste management (its storage and forwarding) are inside the boundaries of the case study.

\section{Methodology}

Two school buildings - Escola Secundária de Paços de Ferreira (site 1) and Escola Secundária da Maia (site 2) - and industrial pavilions (site 3 ) were selected for the demolition case studies. Site 1 was considered a reference scenario with no intervention of the ZeroWIN team, while resource efficiency improvements were planned at site 2. The construction company Edifer Construções Pires Coelho \& Fernandes, S.A. - had been involved in the project as a stakeholder to support the implementation of construction or demolition case studies. The third project (site 3) was the demolition of industrial pavilions in Amadora, close to Lisbon; this demolition project was performed by Ambisider, Recuperações Ambientais, S.A. Potential resource exchanges were investigated in detail for mass-significant material flows and for materials with potentially higher environmental impacts (Obersteiner et al., 2012a).

A detailed data collection process was carried out in order to facilitate quantitative assessment. Work package 7 of the ZeroWIN project focused on quantitative assessment and hence a data collection guideline was established to facilitate data gathering in a systematic and consistent fashion (Obersteiner et al., 2012b). The data collection guideline accompanies a Microsoft Excel template that was provided to C\&D partners; these documents are available by way of the project website (www.zerowin.eu).

In detail, the following steps were taken to achieve the targets mentioned earlier. Apart from a few exceptions, most of the tasks were similar for both the construction project and the demolition projects.

\subsection{Development of a baseline scenario for construction/demolition projects in Portugal}

The general baseline scenario was developed based on estimated averages of construction sites in Portugal, but it was necessary to adapt it to the real specificities of the case study. For demolition site 2, the baseline scenario was built empirically, based on the observation of the techniques used and material flows actually produced in site 1 . For a construction site, a specific baseline scenario must be developed on the basis of the project, and the knowledge experimentally accumulated by the construction enterprise and the research team on the techniques usually applied and the average quantities of material flows that are processed in similar sites. For the case study of the construction of the environmental education centre in Torres Vedras, the municipality provided a detailed construction plan (including a list of activities) that allowed the estimation of expected material inputs.

\subsection{Selection of appropriate case study sites and establishment of objectives and responsibilities with the actors involved}

The main selection criterion for a site was the willingness of the owner and the construction enterprise to implement the measures suggested and supervised by the research team, within the time schedule foreseen for the implementation of construction/demolition works in the ZeroWIN project.

\subsubsection{Brainstorming}

Brainstorming of ideas with the involved stakeholders and the development of a guidance document for the measures implemented on site focused on the measures proposed for

optimised management of materials and waste and industrial symbiosis in materials management

rational management of energy and transport/logistics optimisation and industrial symbiosis in the management of energy and transport

optimised water management and industrial symbiosis in water management.

\subsection{Pre-demolition audit}

Pre-demolition audits were performed based on the previous experience and know-how of the research team. Visits to the buildings to be demolished were performed in order to identify

the type and age of the building, along with relevant specifics concerning construction techniques

the materials present and their respective amounts

the expected quality of arising materials.

\subsection{Selective demolition plan}

The selective demolition plan is a standard methodology developed by CEIFA for demolition works in Portugal. It is recognised as a helpful tool by owners, architects and construction firms (Lourenço, 2007). The goal of selective demolition is to facilitate the recovery of residual materials in order to maximise reuse/recycling and reduce the impact on landfills. Selective demolition involves sequencing the demolition activities to allow the separation and sorting of building materials. 
Waste and Resource Management

Volume 167 Issue WR4
Zero-waste networks in

construction and demolition in

Portugal

Durão, Caixinhas, Osório-Peters

et al.

\subsection{Analysis of data}

Analysis of data included the following.

(a) The identification of processes requiring higher energy and water inputs.

(b) Analysis of global materials inputs and outputs to ensure relevant items were identified and measured in mass units.

(c) Identification of networking potential. For network relationships to be more easily established, proposed exchanges could be performed by making use of a tool such as a web-based resource exchange platform developed within another ZeroWIN case study. However, in this particular situation, the focus was on the identification of industries in the vicinity of the site (depending on their material flows and proximity to the site). The research team (with the support of the municipality) investigated industries in the vicinity of the site with regard to the materials they processed. The municipality identified more than 2000 economic actors within 20$25 \mathrm{~km}$ of the construction site and divided them into sectors and kinds of activity in order to facilitate the identification of real networking potential. With this comprehensive list, CEIFA's team analysed the main materials flows of existing industries. This information was matched with the expected materials flows in the construction site in order to identify the cooperation potentials for further materials, water or energy, and to implement the respective exchanges.

(d) Analysis of possible substitution of input materials. Alternative solutions were investigated with the aim of substituting some of the identified materials, preferably with reusable/recycled materials or materials with lower environmental impacts. It was possible to define some substitutions for recycled, local or more sustainable materials. Possibilities to enhance networking between the actors involved in the construction works were also identified. The suggestions developed by the research team on the identified key materials and possible alternatives integrating reused or recycled materials were discussed in several meetings with the municipality architects and engineers.

(e) Analysis of possible improvements concerning materials outputs. The goal was to find alternative uses for the materials generated on site (e.g. instead of landfilling, search for potential uses as by-products in other industries). A plan was developed for waste materials arising from the site in order to facilitate proper segregation, reduce contamination and improve their final quality. The companies involved in the construction site were required to join an industrial network of recyclers that had achieved high recycling rates in previous years.

\subsection{Development of a list of specific measures to be} undertaken on site to reach the ZeroWIN goals

A set of suggestions, mainly focusing on networking potentials, substitution of input material flows and alternative destinies for outputs, was developed by the research team. The activities were judged in cooperation with the partner responsible for their environmental assessment as significant, moderate and minor with regard to the three ZeroWIN goals (see Table 1).

After discussions with stakeholders the following measures were finally accepted for implementation for the construction project.

(a) Use of concrete cement containing ashes from power plants or other sources as feedstock. Selected waste and by-products such as power plant ashes containing useful components such as calcium, silica, alumina and iron can be used as raw materials in kilns, replacing raw materials such as clay, shale and limestone. Because some materials have both useful mineral content and recoverable calorific value, the distinction between alternative fuels and raw materials is not always clear. For example, sewage sludge has a low but significant calorific value, and burns to give ash containing minerals useful in the clinker matrix.

(b) Reuse of formwork wood. Timber formwork is commonly used for the construction of cast in situ concrete structures because of its versatility and ease of handling. It may form $35-60 \%$ of the total cost of constructing a concrete structure. The reuse of formwork can thus bring about substantial cost savings to contractors. Many construction projects in Singapore utilise site-assembled timber formwork made of lumber and plywood (Ling and Leo, 2000).

(c) Selection of local or at least national materials, thus avoiding long-distance transportation and stimulating the regional economy. What is considered 'local' needs to be defined case by case - for the project goals, distance is linked with GHG emissions and, for the stakeholders, with transport costs. The selection of suppliers that will lead to less transport-related emissions and costs to deliver a product with a specific quality standard seems to be generally accepted as a rational decision.

(d) Substitution of some elements (e.g. steps, parapets and walls for filling with mounting brackets) built in single concrete by light concrete with the incorporation of recycled regranulated cork.

(e) Substitution of extruded polystyrene (XPS) with recycled insulation cork board (ICB)

(f) Substitution of aluminium external shading system (consisting of vertical profiles whose orientation determines the level of exposure to sun/shade) with a wooden system (although Nordic wood because of its resistance characteristics). 


\begin{tabular}{|c|c|c|c|}
\hline & \multicolumn{3}{|c|}{ Impact } \\
\hline & $\begin{array}{l}\text { Reduction of } \\
\text { GHG emissions }\end{array}$ & $\begin{array}{l}\text { Reuse and } \\
\text { recycling of waste }\end{array}$ & $\begin{array}{l}\text { Reduction of } \\
\text { fresh water use }\end{array}$ \\
\hline $\begin{array}{l}\text { Reuse of components such as bricks and ceramics, } \\
\text { insulation materials, carpet tiles, secondary components } \\
\text { from the IT industry (switchers, diodes, etc.), secondary } \\
\text { photovoltaic (PV) panels to provide site lighting }\end{array}$ & Significant & Significant & Significant \\
\hline $\begin{array}{l}\text { Use of recycled materials instead of original ones, } \\
\text { for example }\end{array}$ & Significant & Significant & Significant \\
\hline aggregate to replace virgin material in concrete & & & \\
\hline $\begin{array}{l}\text { glass/ashes from power plants as feedstock in cement, } \\
\text { concrete or ceramics }\end{array}$ & & & \\
\hline $\begin{array}{l}\text { timber or recycled polyvinyl chloride (PVC) window frames } \\
\text { to replace aluminium frames }\end{array}$ & & & \\
\hline $\begin{array}{l}\text { use of electric arc furnace steel (instead of blast-furnace } \\
\text { steel) }\end{array}$ & & & \\
\hline $\begin{array}{l}\text { secondary wood and plastic in production of formwork } \\
\text { insulation materials with recycled fibres, etc. }\end{array}$ & & & \\
\hline $\begin{array}{l}\text { Use of materials with better environmental performance } \\
\text { instead of the ones initially specified }\end{array}$ & Significant & Significant & Significant \\
\hline $\begin{array}{l}\text { Undertake on-site segregation to provide clean secondary } \\
\text { materials }\end{array}$ & Significant & Significant & Significant \\
\hline $\begin{array}{l}\text { Reintegration, on site, of materials/components resulting } \\
\text { from on-site activities }\end{array}$ & Moderate & $\begin{array}{l}\text { Significant for on-site } \\
\text { activities }\end{array}$ & Minor \\
\hline $\begin{array}{l}\text { Reuse of temporary accommodation sites with reused } \\
\text { installations (e.g. pipes, PV modules for power supply) }\end{array}$ & Minor & Minor & Minor \\
\hline $\begin{array}{l}\text { Influence suppliers to offer take-back schemes and 80-20 } \\
\text { ordering (unused wood, bricks, sand, mortar, concrete, } \\
\text { plasterboard, concrete) }\end{array}$ & Minor & Minor & Minor \\
\hline $\begin{array}{l}\text { Identify industries in the vicinity to provide used water } \\
\text { (e.g. vegetable washing water from food industry) }\end{array}$ & $\mathrm{n} / \mathrm{a}$ & $\mathrm{n} / \mathrm{a}$ & $\begin{array}{l}\text { Significant for } \\
\text { on-site activities }\end{array}$ \\
\hline $\begin{array}{l}\text { Use of treated wastewater from municipal treatment } \\
\text { plants or from portable plants on site }\end{array}$ & $\mathrm{n} / \mathrm{a}$ & $\mathrm{n} / \mathrm{a}$ & $\begin{array}{l}\text { Significant for } \\
\text { on-site activities }\end{array}$ \\
\hline
\end{tabular}

Use of grey water or treated wastewater in concrete production

Table 1. Ranking of the potential impacts of individual measures on the overall performance

(g) Substitution of primary aggregates and boulders (collected from rivers or seas) with secondary aggregates (dependent on price).

(h) Reuse of water from a local vegetable-processing industry or wastewater treatment plant (dependent on water transport possibilities/cost-benefit evaluation) for washing, watering the concrete during curing, dust control or other purposes such as mortar preparation (although the contractor is strongly resistant to this latter use).

(i) Substitution of ceiling systems with equivalent systems including recycled plastic. (j) Substitution of false ceiling boards with recycled fibre boards.

For the demolition projects, the following actions were accepted for implementation.

(k) Implementation of a selective demolition procedure with previous and careful removal of dry elements.

(l) Segregation, on site, of at least the following material streams (where existing): mixed metals; mixed inert materials (for on-site crushing and use); plastics; wood; 
Waste and Resource Management

Volume 167 Issue WR4
Zero-waste networks in

construction and demolition in

Portugal

Durão, Caixinhas, Osório-Peters

et al. glass; hazardous materials (separated according to their hazard type).

(m) Substitution of primary aggregates from stone extractions by secondary aggregates produced from $C \& D$ waste recycling (crushing); this substitution is valid for on-site uses if needed (e.g. roads) and use in new construction or refurbishment projects.

(n) Direct reuse of building elements (e.g. windows, doors, toilets, water taps) in new construction or refurbishment.

(o) Use of wood arisings in laminates, fencing, pallets, garden furniture or others.

(p) Use of grey water or treated wastewater for on-site dust control.

(q) Verification of the actual recycling rates achieved by the recyclers in the market. Companies involved were required to cooperate with recyclers achieving high recycling rates that is they were required to choose actual recyclers instead of waste managers that receive waste, store it and then forward it to other waste managers or recyclers.

\subsection{Establishment of contacts with companies for networking}

After the identification of symbiosis potentials with other industries, the next step was to contact companies in order to make these networks operational. The municipality showed a preference in making the institutional contacts with the identified industries.

\subsection{Managing implementation problems}

In the summer of 2012, the contractor was facing insurmountable financial difficulties and work had to be stopped. With the approval of the ZeroWIN project officer, the decision was made to develop the case study at a conceptual level. In early 2013, a new contractor was found and works on the Environmental Education Center were restarted, but only part of the measures proposed could be implemented and evaluated within the ZeroWIN schedule.

\subsection{Monitoring the processes implemented within the ZeroWIN schedule}

Monitoring was performed by direct observations on site, verification of the documentation concerning materials substitutions and waste management, and registers on water and energy consumption.

\section{Results}

\subsection{Construction project}

From a conceptual point of view, the improvement of the construction project as related to the baseline is demonstrated in Figures 1 and 2. Every waste flow could be diverted from disposal in landfill because some materials could be reused at the site itself and others could be forwarded to companies in the vicinity of the site to be used as secondary materials. Further interesting improvements with implications on the overall impact evaluation mainly resulted from resource exchanges (inputs substitution), as described below.

The input materials identified for substitution in the construction project are listed in Table 2. The origins of the materials used in the baseline scenario are listed along with the more sustainable substations proposed for the improved scenario.

In the future, recycled ceramics should also be considered for input substitutions. From a lifecycle perspective, ceramics are very energy- and material-intensive products. Two companies that already incorporated some secondary materials into their ceramic products were found. Several research studies on input substitution in the production of ceramics have been reported (e.g. Ferreira, 2010) but, so far, such solutions have not been established at a commercial level.

With respect to outputs, improvements were suggested to provide $100 \%$ deviation of the residual materials flows from landfill to reuse and recycling. Table 3 summarises the suggestions provided by the research team. Concrete and wood could partially be reused on site. With respect to recycling, the best option could not always be selected in practice, because recycling strongly depends on the quality of the material. Thus, wherever applicable, quality tolerance and quality standards are listed in the table to indicate what requirements need to be met. To ensure confidence in the materials, it is vital that secondary materials comply with the quality criteria, which are either the same as or similar to the criteria for raw resources.

\subsection{Demolition projects}

In the demolition activities, the most significant materials flows in terms of quantities were inert materials (mixtures of concrete, bricks, tiles and ceramics). The pre-demolition audit for site 2 estimated this amount to be $1137 \mathrm{t}$, with the composition given in Figure 3.

Concrete represented more than $50 \%$ of the total amount of inert waste produced on this demolition site. If on-site segregation was properly completed and concrete could be delivered without the inclusion of ceramics or bricks, the recycled concrete produced could be applied in all applications, including the structural elements of a building. According to the technical specifications for the use of recycled aggregates issued by the Portuguese national laboratory for civil engineering (LNEC, 2009a, 2009b, 2009c), recycled concrete from mixed inert waste can, however, only be used in non-structural applications (e.g. road pavements and sub-layers).

Since there are no input materials flows and the on-site water and energy consumption could not be measured, the focus of 


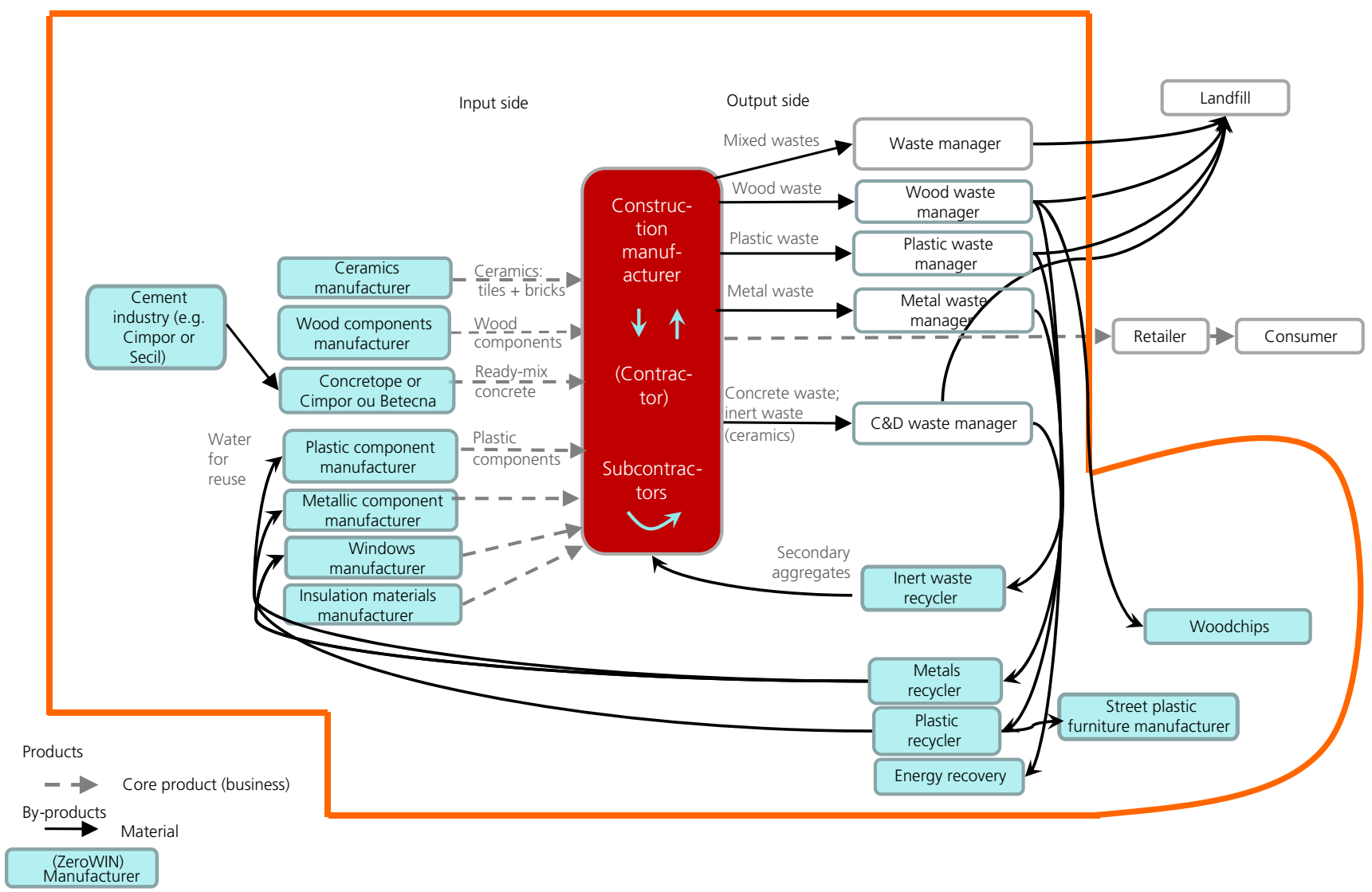

Figure 1. Baseline scenario - current status of construction works in Portugal

the analysis was on the output materials. The most important change that allowed further improvements was the implementation of selective demolition (instead of conventional demolition) techniques on sites 2 and 3 (Figures 4 and 5). Selective demolition is a process where demolition activities are sequenced in a way that allows for the separation and sorting of building materials. The act involves the removal of selective parts of a building, then the removal of portions or components of a structure. This process is used to demolish certain interior finishes without affecting the remaining structure in any way. Following this methodology on site 2 , it was possible to achieve a significant improvement over the baseline established on site 1 where the total amount of solid waste produced (1136 t) went to landfill. Other than asbestos (which must go to special landfill) all other materials produced at site 2 were forwarded to recyclers. The results of the improved scenario (site 2) as opposed to baseline are summarised in Table 4.

In the demolition case study, the reduction target set for solid waste (at least $70 \%$ ) was fully met. In total, $1137 \mathrm{t}$ solid waste was produced in site 2 and $90 \%$ was forwarded to recyclers. Although in some situations the materials delivered for recycling were not as clean as needed (according to the information provided by recyclers, about $10 \%$ out of the recovered materials were forwarded to landfill), a recycling rate of around $89 \%$ could actually be achieved. Reuse (of lamps) contributed only insignificantly to waste reduction (less than $1 \%)$.

Based on the experience gained at sites 1 and 2, a more systematic implementation of the selective demolition procedure was applied on site 3 . The results of this demolition are summarised in Table 5.

Compared to the reference scenario (site 1), important improvements could be completed at site 3 . It was possible to reuse all the inert materials resulting from demolition on the site itself, while all other materials (other than asbestos) were delivered to recyclers. In reality, on-site reuse has associated costs for crushing and placement on the site (machinery movement and fuel consumption), but it is still the best option from both economic and environmental points of view. Reuse 


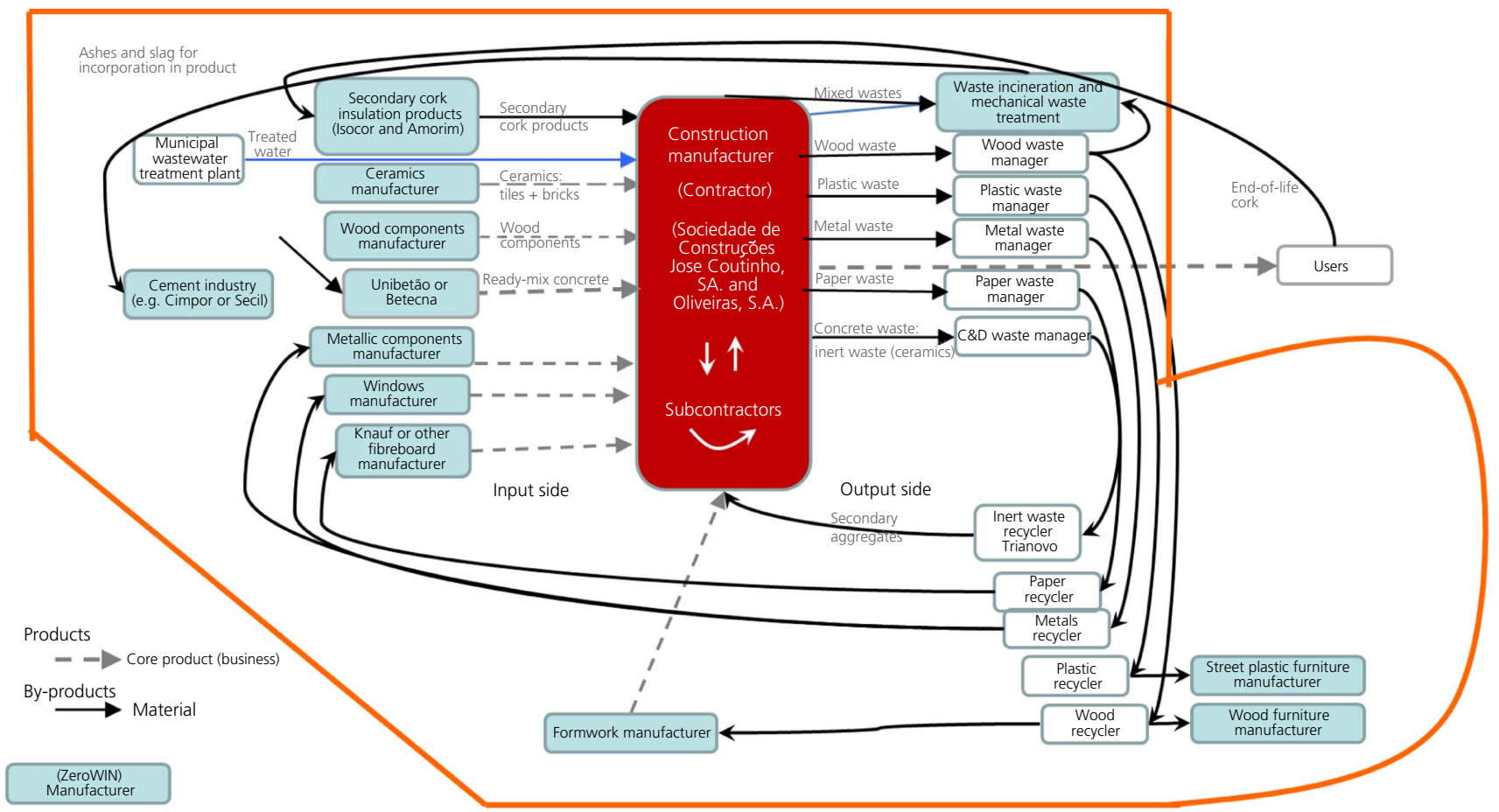

Figure 2. Simplified representation of materials flows in the industrial network developed around the construction site of the environmental education centre in Torres Vedras

outside the site was also considered for wood from the cover structure. To implement this measure, manufacturers of wood laminates and similar wood processors were identified. However, after dismantling it was found that the quality of wood was not good enough for reuse, so instead it was delivered to a recycler (Figure 6). This demonstrates that the quality protocols in place helped to select rational recovery methods for materials.

\subsection{Final remarks}

It is well established that the construction industry's culture and opposition to change are important barriers to effective waste minimisation (Teo and Loosemore, 2001) and that a substantial amount of construction waste originates as a result of poor design (Innes, 2004). Key factors that promote resource efficiency within the C\&D sector include the use of on-site waste sorting methods (Poon et al., 2001), waste auditing and assessment tools (Chen et al., 2002) and waste management practices (McDonald and Smithers, 1998). Achievement of the environmental targets at the reported Portuguese sites was the result of careful preparation of the case studies and intensive communication with the stakeholders. This demonstrates the crucial importance of design, planning and facilitation for the development of industrial symbioses in C\&D works.
A general barrier for the construction sector is the lack of relationship between the concept/design phase and the execution phase (Greenwood, 2003). In fact, several months - or even years - can pass between the planning and execution phases of a building. In the construction case study reported here, this meant that although the municipality was responsible for the design, some of the changes suggested by the research team were rejected because they were not foreseen at an earlier stage (e.g. the substitution of wood laminates).

For the development of industrial symbiosis, a further politically related barrier must also be mentioned. The exchange of waste materials between enterprises depends on the legal status of the materials, which is regulated at European level for each specific waste type. For example, for glass cullet, EU Commission Regulation No 1179/2012 of 10 December 2012 establishes the criteria determining when glass cullet ceases to be waste under directive 2008/98/EC of the European Parliament and of the Council and can be handled as a by-product (EC, 2012). The procedure involves administrative burdens for the producers of waste materials and these must be followed for each specific waste type (copper scrap, metal scrap, etc.).

The ongoing economic crisis was another major barrier that influenced both the selection of construction works to 
Waste and Resource Management

Volume 167 Issue WR4
Zero-waste networks in

construction and demolition in

Portugal

Durão, Caixinhas, Osório-Peters

et al.

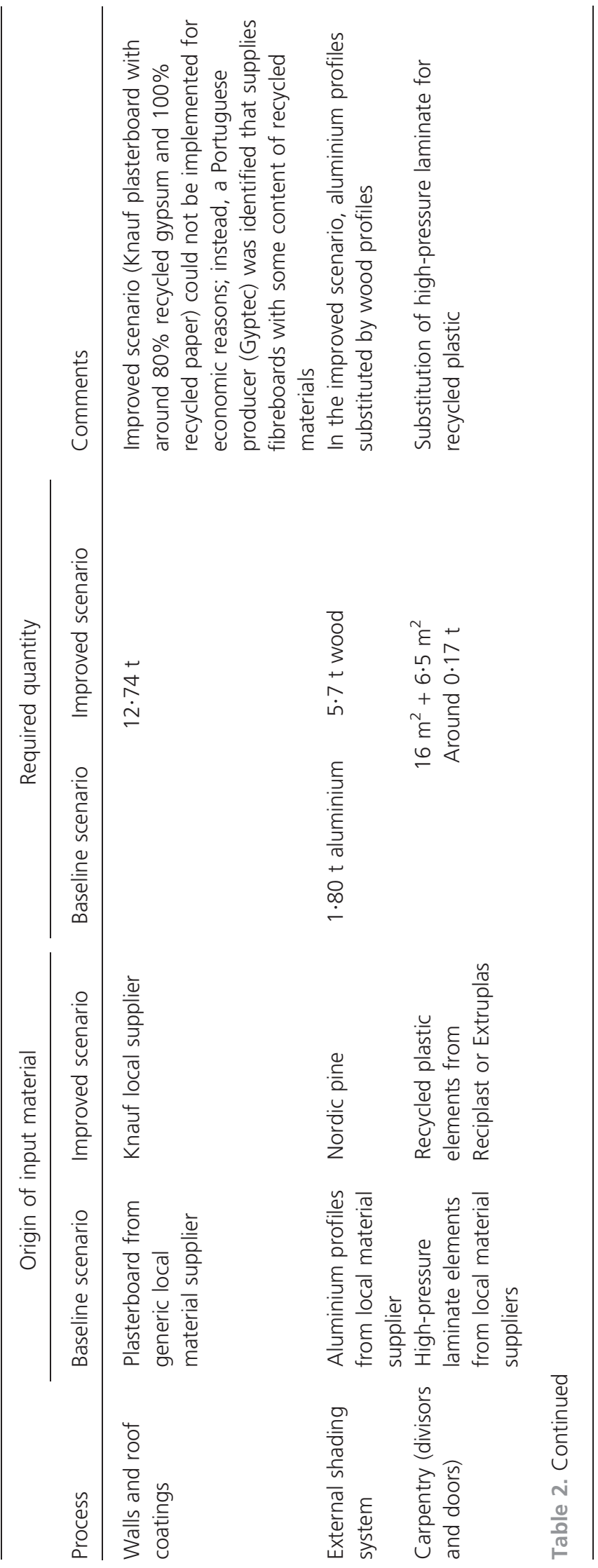




\begin{tabular}{lllll} 
& & Quantities & & Quantities and destination of material \\
\cline { 5 - 5 } $\begin{array}{lll}\text { Output material or } \\
\text { component }\end{array}$ & Process & site: $\mathrm{t}$ & Baseline scenario & Improved scenario \\
\hline Concrete & $\begin{array}{l}\text { Structure and } \\
\text { foundations }\end{array}$ & 71.98 & Waste manager & $\begin{array}{l}\text { Delivery to supplier } \\
\text { for recycling/reuse }\end{array}$
\end{tabular}

Insulation materials Insulation

Wood

Other C\&D

containing

dangerous

substances

Mixed packaging: low-density

polyethylene

(LDPE); paper

and cardboard 4.58/formwork and packaging

\section{$0 \cdot 37$}

$10 \cdot 8$

$0 \cdot 43$

All processes except structure

Around 0.95 paper and $0 \cdot 35 \mathrm{LDPE}$

Waste manager
for further
recycling
Contractor for
reuse
Waste manager

Cork supplier (the cork)

Waste manager for further recycling Contractor for reuse Waste manager Materials suppliers for reuse (packaging)
Quality standards and specifications for the material

For recycling into aggregates, concrete should be clean inert material, with no organics (wood, plastics) or others. It may have metal contaminants because shredders usually have metal segregation incorporated Around half XPS and cork For recycling, materials need to be segregated

Wood from formwork is usually reused until it is too broken or warped Wood contaminated with release agents usually landfilled

Material suppliers receive entire wooden pallets for further reuse Wood for recycling should be free of releasing agents Hazardous materials need to be properly segregated and in containers for forwarding to treatment or disposal

For recycling, materials need to be segregated and free of contaminants (although plastic may be washed before the recycling process)

Table 3. Quantities and destiny changes foreseen for output materials in improved construction scenario in relation to baseline construction scenario

participate in this research project and the involvement of stakeholders in the concept of zero waste. A further economic barrier detected was the low landfill taxes in Portugal, which do not support the diversion of recoverable materials from landfill.

Among the technical barriers, the most important is lack of confidence in the technical quality of alternative sustainable materials and fear of their failure as construction materials (e.g. the use of recycled cement for some non-structural applications was not always well accepted). A way to overcome the general resistance to the use of secondary materials in construction probably requires the implementation of policy measures such as regulations that stimulate/oblige designers to consider input substitution with by-products or recycled 
Waste and Resource Management Volume 167 Issue WR4
Zero-waste networks in construction and demolition in Portugal

Durão, Caixinhas, Osório-Peters et al

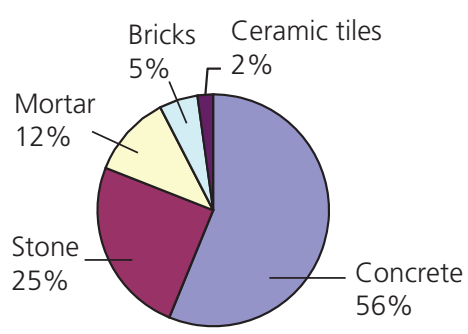

Figure 3. Composition of inert demolition materials at site 2

materials, promote less consuming processes and use materials whose by-products have a high reuse potential in other processes. Finally, aesthetics and architectural concepts were found to present a barrier to some proposed networking solutions. For example, the use of reused wood or recycled materials in public and visible spaces (e.g. wooden shading system, stone pavement) was declined by the architects. Ecodesign and the inclusion of recycled or reused materials as criteria for the evaluation/licensing of buildings or constructions would create an important incentive for project professionals to consider these aspects at the design stage (Greenwood, 2003).

In spite of all difficulties met, the case studies have shown that it is possible to achieve zero-waste goals on $C \& D$ sites by exploring nearby industrial networking potentials. A prerequisite for the success of industrial networking and increasing resource efficiency is the implementation of accurate waste management logistics at the site to ensure proper separation of different types of materials.

\section{Conclusion}

The reported case studies show that implementation of the general framework set for the ZeroWIN project was challenging in the construction sector. Several recommendations have

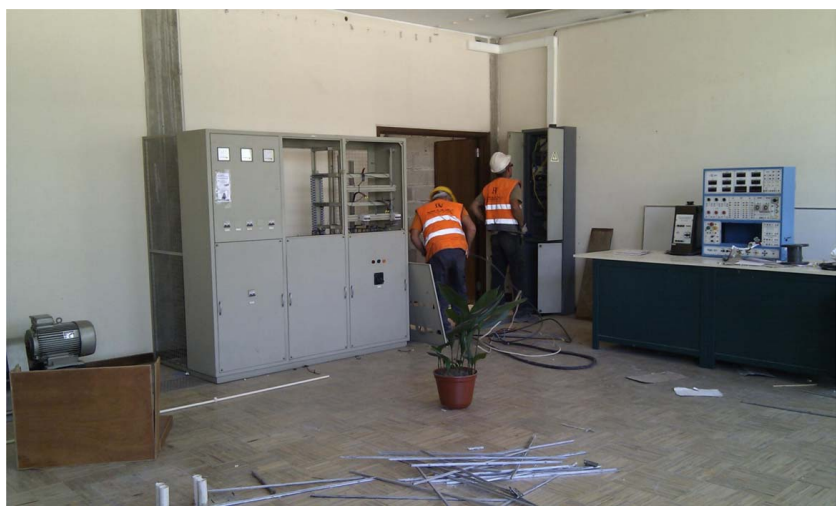

Figure 4. Hand removal of dry elements in site 2

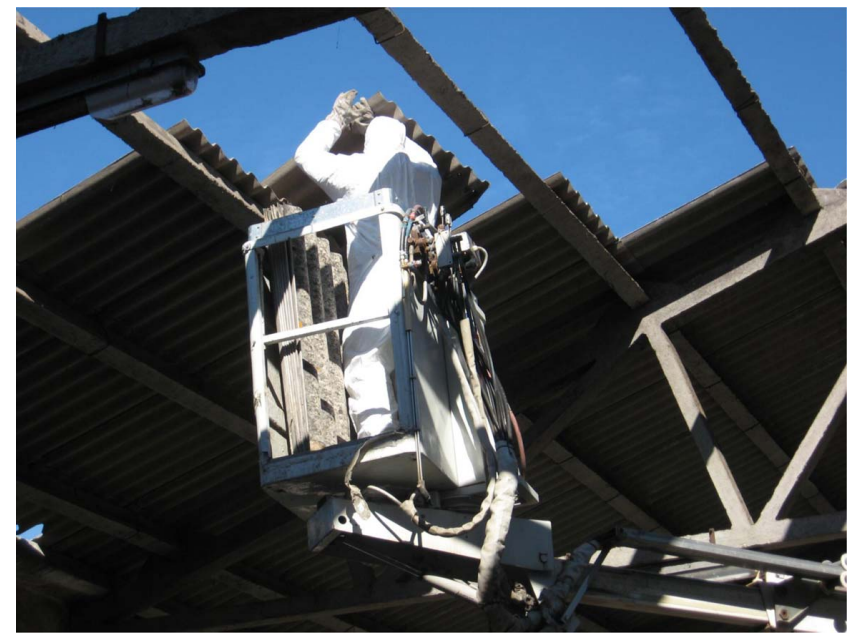

Figure 5. Careful removal of asbestos in site 3

been developed to support industrial networking around a construction site, and it seems to be easier to establish an industrial network when an external agent acts as a facilitator. The main tasks of a facilitator are to identify industrial network potentials and analyse materials flows in order to detect possibilities for materials exchange and substitution with other economic activities in the surroundings. In addition, the facilitator promotes contacts, resolves problems or conflicts and evaluates project progression. In this case study, the research team played this role. Owners and promoters that are aware of the importance of industrial networks to achieve better environmental performance in construction projects understand the relevance of a network facilitator. Intensive awareness-raising is needed in the construction sector in order to build up favourable framework conditions to spread this concept.

The demolition projects demonstrated progressive improvement - site 1 represented 'business as usual', site 2 was a trial to implement a selective demolition plan (not fully implemented) and site 3 showed the best results in selective demolition. Detailed planning of the methodology and close contact with the involved stakeholders proved to be very important. In general, the targets of the ZeroWIN project and the objectives of the case study were achieved. The deviation of waste streams from landfill to recyclers normally induces cost advantages, and the stakeholders thus generally accepted the measures proposed unless additional costs were associated with their implementation. Industrial networking directly involving manufacturing industries (direct reuse of materials/resource exchange) was shown to be difficult in demolition projects, due to both the degradation stage of materials and the resistance of the actors involved. 


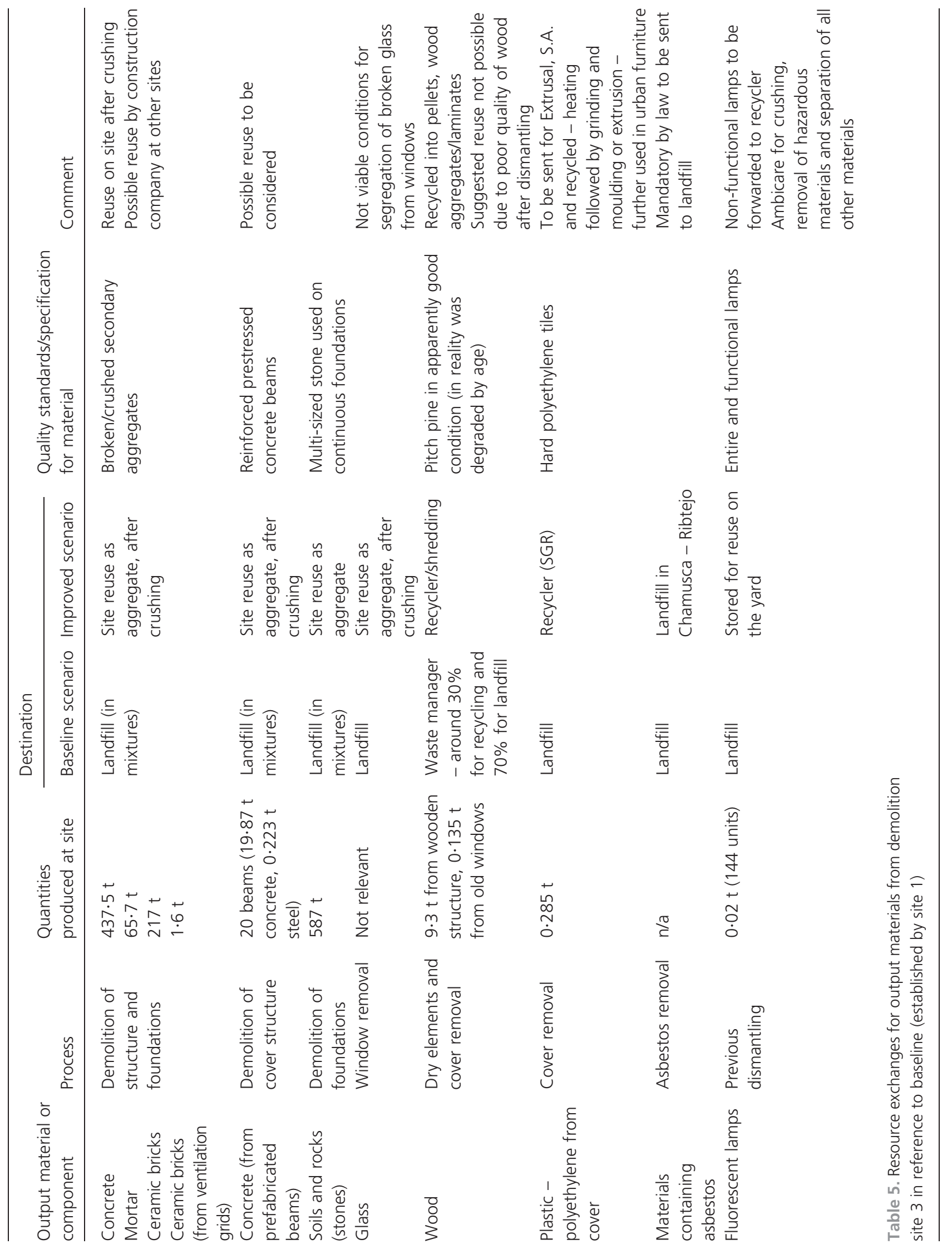


Durão, Caixinhas, Osório-Peters

et al.

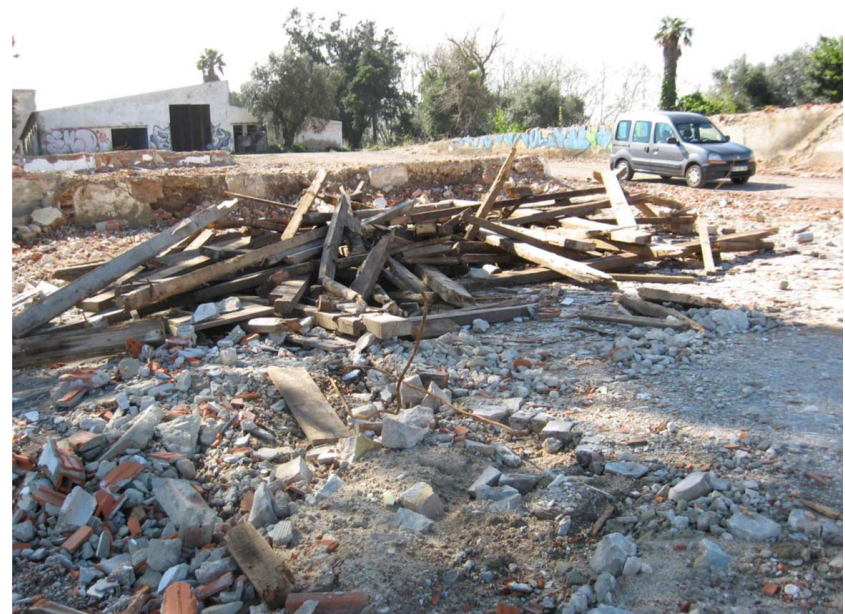

Figure 6. Segregated wood for recycling at site 3

In the construction sector, further research is needed with regard to the manufacture of construction materials incorporating secondary materials (ceramics, steel, glass, cement, concrete, etc.) without compromising product quality. Standards and regulations need to be established for materials with recycled content. Research needs specifically related to demolition were also detected - these are mainly related to the incorporation of secondary materials in new products (both for construction products or other sectors) and the direct incorporation of demolition by-products on construction works.

Mechanisms to simplify the procedures related to the certification of secondary materials and recognition of by-products should be developed and tested.

Alternative demolition processes must be better studied. Selective demolition requires special techniques and, at the moment, the best standards are achieved with labour-intensive approaches. New technical developments are needed to reduce the time and costs involved in selective demolition so that it becomes more attractive to both owners/promoters and contractors.

\section{Acknowledgement}

The research leading to these results received funding from the European Community's Seventh Framework Programme (FP7/2007-2013) under grant agreement 226752.

\section{REFERENCES}

Balaras C, Gaglia A, Georgopoulou E et al. (2007) European residential buildings and empirical assessment of the Hellenic building stock, energy consumption, emissions and potential energy savings. Building and Environment 42(3): 1298-1314.

Chen Z, Li H and Wong TC (2002) An application of bar-code system for reducing construction wastes. Automation in Construction 11(5): 521-533.

Coelho A and Brito J (2010) Traditional vs selective demolition comparative economic analysis applied to Portugal. Proceedings of Portugal SB10 Sustainable Buildings Affordable to All, Lisbon, Portugal, pp. 699-704.

Curran T and Williams ID (2012) A zero waste vision for industrial networks in Europe. Journal of Hazardous Materials 207-208: 3-7.

den Boer E and Wolf M (eds) (2011) Concept Papers for All Networks/Pilot Applications. Austrian Society for Systems Engineering and Automation, Vienna, Austria, Deliverable 6A.1 of collaborative project ZeroWIN, Towards zero waste in industrial networks (grant agreement number 226752).

den Boer E, Williams I and Curran T (eds) (2012) Midterm Progress Reports for All Networks/Pilot Applications.

Austrian Society for Systems Engineering and Automation, Vienna, Austria, Deliverable 6A.2 of collaborative project ZeroWIN, Towards zero waste in industrial networks (grant agreement number 226752).

EC (European Commission) (2012) 433 Final. Communication from the Commission to the European Parliament and the Council Strategy for the sustainable competitiveness of the construction sector and its enterprises. EC, Brussels, Belgium. Environment Agency (2011) Sustainable Construction: Position Statement. See http://www.environment-agency.gov.uk/ research/library/position/41239.aspx (accessed 13/12/2011).

Ferreira LS (2010) Caracterização de Lamas de ETA's para Aplicação na Indústria Cerâmica. Master's thesis, Aveiro University, Portugal. See http://ria.ua.pt/handle/10773/ 2740 (accessed 14/12/2012) (in Portuguese).

Greenwood R (2003) Construction Waste Minimisation - Good Practice Guide. Centre for Research in the Build Environment, Cardiff, UK.

Ines S (2004) Developing tools for designing out waste pre-site and on-site. Proceedings of Minimising Construction Waste Conference: Developing Resource Efficiency and Waste Minimisation in Design and Construction, London, UK.

Ling YY and Leo KC (2000) Reusing timber formwork: importance of workmen's efficiency and attitude. Building and Environment 35(2): 135-143.

LNEC (Laboratório Nacional de Engenharia Civil) (2009a) LNEC E 471-2009 - Guide for the use of coarse recycled aggregates in concrete. See http://www.apambiente.pt/ index.php?ref $=16 \&$ subref $=84 \&$ sub2ref $=197 \&$ sub3ref $=283$ (accessed 03/05/2013).

LNEC (2009b) LNEC E 473-2009 - Guide for the use of recycled aggregates in unbound pavement layers. See http://www. apambiente.pt/index.php?ref $=16 \&$ subref $=84 \&$ sub2ref $=197 \&$ sub3ref $=283$ (accessed 03/05/2013).

LNEC (2009c) LNEC E 474-2009 - Guide for the use of recycled materials coming from construction and demolition waste in embankment and capping layer of transport 
infrastructures. See http://www.apambiente.pt/index. php?ref $=16 \&$ subref $=84 \&$ sub2ref $=197 \&$ sub3ref $=283$ (accessed 03/05/2013).

Lourenço IC (2007) Optimização de Sistemas de Demolição Demolição Selectiva. Master's thesis, Technical University of Lisbon, Portugal. See https://dspace.ist.utl.pt/bitstream/ 2295/143697/1/Documento\%20Dissertacao.pdf (accessed 15/05/2013) (in Portuguese).

McDonald B and Smithers M (1998) Implementing a waste management plan during the construction phase of project: a case study. Journal of Construction Management and Economics 16(1): 71-78.

Miranda C (2009) Modelo para a Gestão de Resíduos de Construção e Demolição - uma solução para as empresas de construção civil. Master's thesis, Açores University, Portugal. See https://repositorio.uac.pt/bitstream/10400.3/ 408/1/DissertMestradoCatarinaFAMiranda2009.pdf (accessed 15/05/2013) (in Portuguese).

Obersteiner G, Beigl P, Pertl A and Scherhaufer S (2012a) Report on Assessments of Pilot Cases: Mid-term Assessment, Austrian Society for Systems Engineering and Automation. Vienna, Austria, Deliverable 7.2 of collaborative project ZeroWIN, Towards zero waste in industrial networks.

Obersteiner G, Beigl P, Pertl A and Scherhaufer S (2012b) Data Collection Guidelines. Austrian Society for Systems Engineering and Automation, Vienna, Austria, Deliverable
7.1 of collaborative project ZeroWIN, Towards zero waste in industrial networks.

Pacheco Torgal F (2012) Betões Geopoliméricos, Maquinaria 21 Jun 2012, p. 56. See http://repositorium.sdum.uminho.pt/ bitstream/1822/19847/1/Torgal\%20-\%20Junho.pdf (accessed 02/04/2012) (in Portuguese).

Poon CS, Yu ATW and Ng LH (2001) On-site sorting of construction and demolition waste in Hong Kong. Resources, Conservation and Recycling 32(2): 157-172.

Smith R, Kersey J and Griffiths P (2002) The Construction Industry Mass Balance: Resource Use, Wastes and Emissions. See http://www.massbalance.org/downloads/ projectfiles/1406-00112.pdf (accessed 28/11/2011).

Spence R and Mulligen H (1995) Sustainable development and the construction industry. Habitat International 19(3): 279292.

Teo M and Loosemore MM (2001) A theory of waste behaviour in the construction industry. Construction Management and Economics 19(7): 741-751.

Vadera S, Woolas P, Flint C et al. (2008) Strategy for Sustainable Construction. See http://www.bis.gov.uk/files/file46535.pdf (accessed 19/12/2011).

Yan H, Shen Q, Fan LCH et al. (2009) Greenhouse gas emissions in building construction: A case study of one peking in Hong Kong. Building and Environment 45(2010): 949-955.

\section{WHAT DO YOU THINK?}

To discuss this paper, please email up to 500 words to the editor at journals@ice.org.uk. Your contribution will be forwarded to the author(s) for a reply and, if considered appropriate by the editorial panel, will be published as discussion in a future issue of the journal.

Proceedings journals rely entirely on contributions sent in by civil engineering professionals, academics and students. Papers should be 2000-5000 words long (briefing papers should be $1000-2000$ words long), with adequate illustrations and references. You can submit your paper online via www.icevirtuallibrary.com/content/journals, where you will also find detailed author guidelines. 